\title{
Firms under Judicial Protection: A Profitable Investment?
}

\author{
Xavier Brédart ${ }^{1}$ \\ ${ }^{1}$ Warocqué School of Business and Economics, University of Mons, Mons, Belgium \\ Correspondence: Xavier Brédart, Warocqué School of Business and Economics, University of Mons, Place Warocqué, \\ 17, 7000, Mons, Belgium. Tel: 32-65-373-213. E-mail: xavier.bredart@umons.ac.be
}

Received: April 2, 2014

Accepted: April 17, 2014

Online Published: June 23, 2014

doi:10.5430/rwe.v5n2p14

URL: http://dx.doi.org/10.5430/rwe.v5n2p14

\begin{abstract}
The objective of this article is to observe stock prices of firms around their filing for liquidation or reorganization procedure. Through a methodology developed for this purpose, we compare the stock returns of these firms with that of "similar" companies but not affected by this type of event. The results report higher average market profitability for firms under protection of the American bankruptcy code for a holding period of between 1 and 5 months after the announcement date.
\end{abstract}

Keywords: bankruptcy, Chapter 7, Chapter 11, price index

\section{Introduction}

The analysis of the reactions of economic agents following the notification of filings for chapters 7 and 11 has been the subject of very few studies (Chi and Tang, 2007). Compared with the recent series of bankruptcies involving some large companies, this topic is yet of significant importance. The study of Bris et al. (2006), lead over the period from 1995 to 2001, deals with the impact of the filing for reorganization process (chapter 11) on the profitability of shares of the concerned companies; these authors mention their regret for not being able to achieve their analysis on a recession time. In the same vein, Brédart and Finet (2012) lead an event analysis over the period 2007-2008.

The academic literature provides more about the reaction of the securities before (Kalay et al 2007) and after (Eberhart et al., 1999; Cunney and Thomas, 2004) the liquidation or reorganization process. However, it is relatively quiet about the evolution of stock prices during this transitional period. Coping with significant challenges and thus coming into conflict with the standard listing of major exchanges, a large number of failing firms is forced to "delisting" on Over The Counter (OTC) markets around the notification of filing for bankruptcy protection. Contrary to popular belief, there is a relatively active market for the exchange of securities linked to these companies for the duration of the judicial process. According to Li and Zhong (2013), more than half of these shares are subject to daily exchanges. Kumar (2009) describes the profile of investors trading such securities. These ones would mainly be up to $90 \%$ individual investors characterized by a high risk tolerance and a high gains expectancy. These findings prompt Kumar (2009) to compare these securities with lottery tickets characterized by a low initial investment, a very low probability of significant gain and a high probability of loss of the invested amount.

The purpose of this article is to figure out the reaction of the U.S. stock market around the notification of a judicial protection process during the subprime crisis. These companies can transfer their listing on an OTC market. Therefore, it is possible to analyze the reaction of shareholders around this event. Conventionally, highlighting the judgment made by equity investors is apprehended through event studies conducted on a single sample of companies.

The originality of our analysis lies in the development and use of a comparative methodology conducted on a paired sample, including "failing" (with filing for chapter 7 or 11 of the American bankruptcy code) and healthy firms (which did not resort to a law of bankruptcy protection). This personal methodology, involving price indexes calculation, will assess the profitability of companies under judicial protection while avoiding drawbacks inherent in the conventional event methodologies. Comparing our two subsamples of firms showed a differential in financial returns favorable to companies involved in a bankruptcy protection process for certain holding periods. The results of this study allow highlighting the potentially attractive returns of firms under judicial protection process and opening the door to a renewed interest in the academic world for these values.

Moreover, this study may allow investors to assess the market reaction following the release of a process of liquidation or reorganization and thus adjust their investment portfolio. 
The rest of the article is as follows. In the first part, we review the literature related to our research question. The second part will present our population and detail the methodology. The third part of this article will present the results of analyzes comparing the profitability of stocks under a liquidation or reorganization process and the profitability of entities that did not encounter any problems of this kind. The last section will discuss the results and propose research avenues.

\section{Literature Review}

Intuitively, the notification of reorganization or liquidation process induces among the investors a loss of confidence in the ability of the company to generate future benefits. We can therefore expect a significantly negative effect on profitability and, as a consequence on the market valuation. In addition, reorganizations and liquidations are usually very expensive and consume a significant portion of the company's value (Beaver, 1968). According to Clark and Weinstein (1983), the notification of a judicial protection process may be regarded by the shareholders as a signal of potential problems inherent to the enterprise; for example, increasing the likelihood that shares may become worthless. Their study, based on a sample of 36 companies declared in default between 1938 and 1979, concludes in a decline in profitability around the release of the announcement. In a similar vein, Warner (1977) reported results in line with the hypothesis of market efficiency; in other words, the negative effect of the notification is quickly grasped by the stock market. In addition, studies of Warner (1977), Aharony et al. (1980) and Clark and Weinstein (1983) mention significant falls of profitability in the days preceding the notification. These authors explain their results by the existence of warning articles published by the financial press (an explanation shared by Chen and Church (1996)). Also according to Warner (1977), Aharony et al. (1980) and Clark and Weinstein (1983) studies, let us note that, if a part of the adjustment is anticipated, the fall of profitability is particularly important three days around the notification. Finally, according to the study of Altman (1971), shareholders would suffer a capital loss of about $26 \%$ over the period from one month before to one month after the release of the announcement. Regarding to a more recent study (Chi and Tang, 2007), a positive abnormal return of $25 \%$ is reported within the month following the date of the announcement.

Regarding the effect of the notification over a longer period of time (over one month after the announcement), the efficient market theory implies that stock adjustments would already have taken place previously (Altman and Brenner, 1981); therefore, no abnormal returns should be observed during this period. That said, events such as the development of the plan of reorganization or its acceptance by the Court would tend to reassure shareholders, resulting in a more optimistic feeling (Morse and Shaw, 1988; Chi and Tang, 2005). Moreover, according to the study of Jessup and Upson (1970), OTC markets would show some potentiality in terms of profitability, sometimes able to supplant the traditional markets such as the NYSE. However, according to Li and Zhong (2013), investment in securities of companies under judicial protection is, on average, unprofitable. Brédart and Finet (2012) reported a trend to abnormal positive returns for holding periods superior to one trading month after the notification for liquidation or reorganization process.

Regarding comparative studies between corporate profitability of companies under judicial protection and that of other firms, the study of Altman (1998), over the period 1980-1993, concludes to an outperformance of the first ones. In addition, Mooradian and Hotchkiss (1997), Indro al. (1999) and Chi and Tang (2005) report that the returns of the securities under a judicial protection process can be positive and significantly higher than those of securities not involved in such a procedure, and this for several holding periods. These results can be related with significant increases in operational performance achieved by these firms during the period of reorganization (Kalay et al., 2007).

The current study makes it possible, through the use of a personal methodology, to compare the evolution of the prices of shares of two groups of firms (the healthy group and the failed group) around the potential announcement for liquidation or reorganization procedure.

\section{Data and Methodology}

Inclined to compare the behavior on the stock market of companies under judicial protection procedure with firms not involved in a failure process, our analysis aims at outsourcing the analysis of the performance. Conventional event studies highlight abnormal performances by extrapolating returns on the basis of the past behavior of the considered firms. We carry out, in this article, a comparative analysis of the profitability of companies under liquidation or liquidation process by using a methodology developed for this purpose. Specifically, we compare the stock returns of a sample of 156 companies that resorted to a bankruptcy protection law to a share portfolio backed to a paired sample of firms that have not experienced this kind of event during the considered period of analysis. Unlike what is done in conventional event studies, we change the benchmark test by comparing the returns of our original securities, not to those watched in the past, but to those of securities from 'similar' companies for their size, their area 
of activity and their original market. The instability of the market environment typical of our period of analysis leads us, in fact, to express some reservations about extrapolating data of returns from past returns as done in the framework of classical event studies. Comparing two securities portfolios, through the building of a price index, avoids this problem by analyzing the profitability of our two subsamples for an identical period.

\subsection{Data}

The bursting of the housing bubble in July 2007 led to a substantial drop in the major indexes, pushing a large number of companies to resort to a bankruptcy procedure. The U.S. market having allowed companies under such a procedure to transfer their listing on the OTC market, it is possible to analyze the behavior of shareholders around this event. In addition, the subprime crisis born in the United States, companies listed in the United States have logically been the first to be affected. For these reasons, we decided to focus our analysis on companies previously listed on the New York Stock Exchange (NYSE), the American Stock Exchange (AMEX) or the National Association of Securities Dealers Quotation System (NASDAQ), these firms having disclosed their filing for chapter 7 or 11 (Gilson, 1989) between July 2007 and December 2009 and having transferred their listing during this period to a less regulated market. So, we listed 156 companies matched to the mentioned criteria given. These companies, among which we will name as examples American Home Mortgage, Lehman Brothers, Washington Mutual or General Motors, represent our bunch for analysis. During this time window of 30 months, the composite indexes of NYSE, AMEX and NASDAQ have respectively fell from 9,997 to 7,184 dots (-39\%), from 2,359 to 1,824 (-29\%) dots and from 2,632 to 2,269 dots (-16\%). Moreover, the number of bankruptcies has increased sharply during this period. We compared this batch to a paired sample of firms that did not resort to a bankruptcy protection procedure during the period considered. These were chosen for their "similarity" with our firms previously identified. The similarity implies three criteria: total assets, the area of activity, (Mossman et al, 1998) and the original quotation market. In this way, we selected 156 "lookalikes" among all listed companies on the NYSE, NASDAQ and AMEX. Regarding data collection, information about judicial protection procedures and about transfers of listing come from Bloomberg. The market prices of our total sample of 312 companies were collected from Datastream.

\subsection{Methodology}

In order to achieve our comparative study, we develop in this section, a methodology involving the determination of price indexes. This technique consists in creating, for each of our two equity portfolios, an index mirroring the evolution of the average price. From a practical point of view, we work in two steps.

The first step consists in creating a first index based on stock prices of the securities "backed" to our initial bunch of companies (those who experienced difficulties resorted to bankruptcy protection procedure). In order not to be disturbed by our reference event, we set the initial value of our equity index (basic price) two months before the filing date for liquidation or reorganization procedure.

Afterwards, we compare, for each company, the following days prices (up to 100 days after the disclosure) to this basic price to get our index.

$$
\text { Index }_{i t}=\frac{\text { Price }_{i t}}{\text { Basic price }_{i}}
$$

With,

Index $i t$ : the value of the index of prices of firm $\mathrm{i}$ at time $\mathrm{t}$;

Price $_{i t}$ : the price of firm i at time t;

Basic price $_{i}$ : the basic price of firm $i$.

Then we calculated, for each day, an average of the indexes obtained for all the 156 considered companies. This first step allows us to determine the date for which the minimum value of the first index is observed.

The second step of this reasoning consists in creating two new indexes - one matched to securities backed to companies having been put under judicial protection procedure, the other one to their "look-alikes" - whose initial values (basic prices) are set on the day determined at the end of the previous step.

As in the first step, we then compared, for each company, the following days prices (up to 100 days after the notification) with their respective basic price to get our two new indexes (Note 1). For each of the two indexes, we then calculated, for each day, the mean value for our two subsamples. The comparison of such indexes allows us to compare the evolution of the market prices of our two subsamples avoiding drawbacks inherent to the conventional event methodologies. Finally, in order to formalize the comparison of our two indexes, we undertook a means 
comparison test. However, before making our means comparison test, we need to test the equality of variances of our two sub-samples. To this end, we calculated a statistical Fisher's (F). This preliminary test performed, we tackled to the means comparison test itself by stating the null hypothesis that these are equal.

With,

$$
H 0: \bar{X}_{1}=\bar{X}_{2}
$$

$\bar{X}_{1}$ : Average value of the first subsample;

$\bar{X}_{2}$ : Average value of the second subsample;

In order to test the null hypothesis of equality of means, we calculated the statistics "t Student " as follows:

$$
t_{o b s} \cdot=\frac{\bar{X}_{1}-\bar{X}_{2}}{\sqrt{\frac{\sigma_{1}{ }^{2}}{n_{1}}+\frac{\sigma_{2}{ }^{2}}{n_{2}}}}
$$

with,

$\mathrm{t}_{\mathrm{obs}}$ : "statistic student" deciding rejection or not of the null hypothesis;

$\bar{X}_{1}$ : Average value of the first subsample;

$\bar{X}_{2}$ : Average value of the second subsample;

$\sigma_{1}$ : Standard deviation of the first subsample;

$\sigma_{2}$ : Standard deviation of the second subsample;

$n_{1}:$ Size of the first subsample;

$n_{2}$ : Size of the second subsample.

Let us note that, in case of rejection of the prior hypothesis of equal variances, the number of degrees of freedom must be adjusted by using the formula developed by Welch (1938).

Figure 1 summarizes the different steps of the created methodology to compare the evolution of the market prices of our two subsamples of companies.

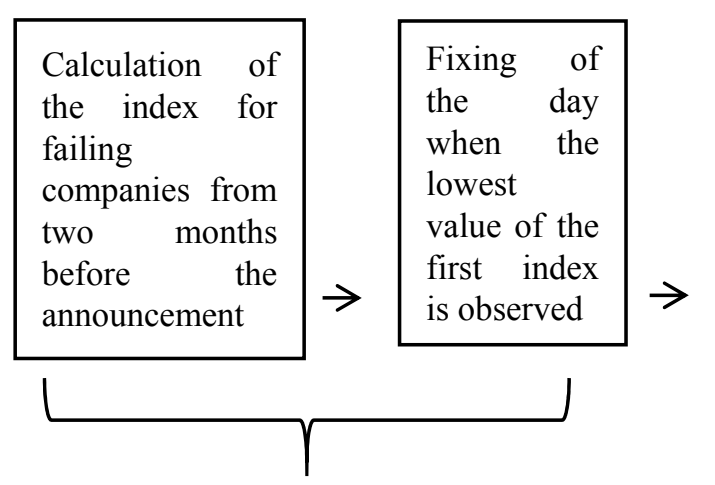

Step 1

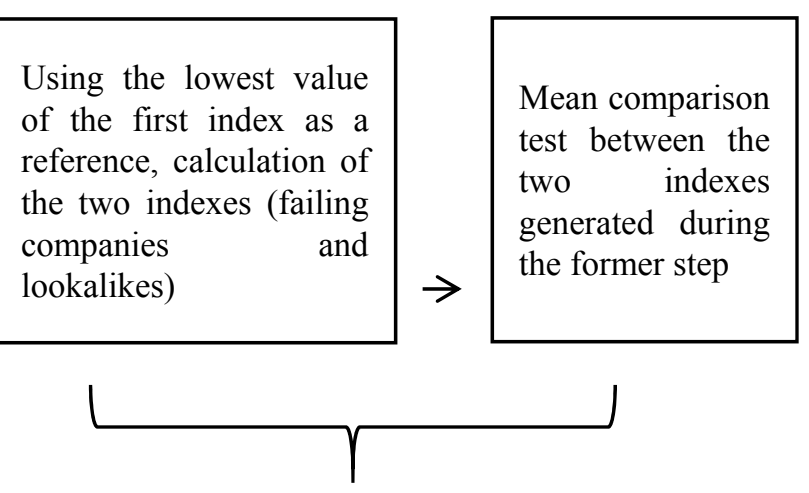

Step 2

Figure 1. The different steps of the methodology 


\section{Results}

\subsection{Descriptive Statistics}

Let us remember that for each of the companies under judicial protection process, we considered a company in the same area of activity, with a comparable size, and, inherent to the same quotation market but having not known major (or at least comparable) problems over the period 2007-2009. So, we got a paired sample of 312 companies for which we identified the market prices. Among our initial population of 156 companies under liquidation or reorganization procedure, four of them were excluded from our analysis because we have not been able to get data on their market value (Note 2).

Table 1 shows, in absolute and relative terms, the data concerning the original quotation market of our initial bunch of 152 companies under liquidation or reorganization procedure. In terms of size, the average total of the assets of our sample of failing firms amounts to USD 10,489,527,000.

Table 1. Firms under liquidation or reorganization process according to their original market

\begin{tabular}{lll}
\hline Market of origin & Number & Percentage \\
\hline NASDAQ & 79 & $51.97 \%$ \\
NYSE & 52 & $34.21 \%$ \\
AMEX & 21 & $13.82 \%$ \\
\hline
\end{tabular}

Table 2 shows the distribution of companies from our original sample by area of activity. These are obviously manufacturing, financial and real estate sectors that have been most impacted by the crisis. While the crisis had first been contained to the real estate sector, in a second time, it passed on the financial sector (Aglietta, 2008). Due to the credit crunch, the crisis has also affected the industrial sector (i.e. the real economy (Attali, 2008)).

Table 2. Firms under liquidation or reorganization process per area of activity

\begin{tabular}{llll}
\hline $\begin{array}{l}\text { SIC (Note 3) } \\
\text { code }\end{array}$ & Title & Number & Percentage \\
\hline $\mathbf{1}$ & Mining and construction & 13 & $8.55 \%$ \\
$\mathbf{2 , 3}$ & Factories & 73 & $48.03 \%$ \\
$\mathbf{4}$ & Transports, communications, Electricity, gas and sanitary & 10 & $6.58 \%$ \\
$\mathbf{5}$ & services & 12 & $7.89 \%$ \\
$\mathbf{6}$ & Wholesale \& retail & 33 & $21.71 \%$ \\
$\mathbf{7 , 8}$ & Finance, insurance and Real Estate & 11 & $7.24 \%$ \\
\hline
\end{tabular}

\subsection{Comparison of Price Indexes}

The first step of our analysis, performed only on the basis of share prices of our bunch of firms that have experienced difficulties linked to bankruptcy, consists in creating an index starting two months before the notification date of filing for chapter 7 or 11 . To this end, for each of the 152 involved companies, we compared up to 100 days after the event, the daily share price with the basic price.

Table 3 reports the values of our first index. 
Table 3. Index constructed from the bunch of firms placed under a liquidation or reorganization procedure

\begin{tabular}{|c|c|c|c|c|c|c|c|c|c|}
\hline Day & $\begin{array}{l}\text { Price } \\
\text { index }\end{array}$ & Day & $\begin{array}{l}\text { Price } \\
\text { index }\end{array}$ & Day & $\begin{array}{l}\text { Price } \\
\text { index }\end{array}$ & Day & $\begin{array}{l}\text { Price } \\
\text { index }\end{array}$ & Day & $\begin{array}{l}\text { Price } \\
\text { index }\end{array}$ \\
\hline-40 & 1 & -10 & 0.745 & 18 & 0.237 & 46 & 0.272 & 74 & 0.299 \\
\hline-37 & 0.978 & -9 & 0.739 & 19 & 0.255 & 47 & 0.269 & 75 & 0.298 \\
\hline-36 & 0.967 & -8 & 0.737 & 20 & 0.242 & 48 & 0.284 & 76 & 0.3 \\
\hline-35 & 0.961 & -7 & 0.721 & 21 & 0.246 & 49 & 0.282 & 77 & 0.314 \\
\hline-34 & 0.953 & -6 & 0.706 & 22 & 0.258 & 50 & 0.285 & 78 & 0.309 \\
\hline-33 & 0.93 & -5 & 0.68 & 23 & 0.252 & 51 & 0.296 & 79 & 0.313 \\
\hline-32 & 0.929 & -4 & 0.675 & 24 & 0.251 & 52 & 0.289 & 80 & 0.307 \\
\hline-31 & 0.921 & -3 & 0.651 & 25 & 0.237 & 53 & 0.3 & 81 & 0.319 \\
\hline-30 & 0.907 & -2 & 0.641 & 26 & 0.237 & 54 & 0.296 & 82 & 0.34 \\
\hline-29 & 0.902 & -1 & 0.615 & 27 & 0.299 & 55 & 0.281 & 83 & 0.344 \\
\hline-28 & 0.894 & 0 & 0.463 & 28 & 0.311 & 56 & 0.28 & 84 & 0.344 \\
\hline-27 & 0.884 & 1 & 0.338 & 29 & 0.308 & 57 & 0.275 & 85 & 0.341 \\
\hline-26 & 0.885 & 2 & 0.345 & 30 & 0.333 & 58 & 0.276 & 86 & 0.328 \\
\hline-25 & 0.888 & 3 & 0.338 & 31 & 0.333 & 59 & 0.274 & 87 & 0.325 \\
\hline-24 & 0.877 & 4 & 0.294 & 32 & 0.315 & 60 & 0.27 & 88 & 0.326 \\
\hline-23 & 0.852 & 5 & 0.294 & 33 & 0.304 & 61 & 0.273 & 89 & 0.327 \\
\hline-22 & 0.851 & 6 & 0.279 & 34 & 0.326 & 62 & 0.266 & 90 & 0.324 \\
\hline-21 & 0.837 & 7 & 0.264 & 35 & 0.323 & 63 & 0.269 & 91 & 0.332 \\
\hline-20 & 0.867 & 8 & 0.262 & 36 & 0.331 & 64 & 0.282 & 92 & 0.335 \\
\hline-19 & 0.83 & 9 & 0.27 & 37 & 0.334 & 65 & 0.287 & 93 & 0.327 \\
\hline-18 & 0.827 & 10 & 0.261 & 38 & 0.309 & 66 & 0.286 & 94 & 0.324 \\
\hline-17 & 0.837 & 11 & 0.254 & 39 & 0.319 & 67 & 0.297 & 95 & 0.321 \\
\hline-16 & 0.806 & 12 & 0.241 & 40 & 0.326 & 68 & 0.295 & 96 & 0.327 \\
\hline-15 & 0.811 & 13 & 0.242 & 41 & 0.308 & 69 & 0.301 & 97 & 0.314 \\
\hline-14 & 0.825 & 14 & 0.239 & 42 & 0.305 & 70 & 0.303 & 98 & 0.317 \\
\hline-13 & 0.782 & 15 & 0.242 & 43 & 0.289 & 71 & 0.3 & 99 & 0.309 \\
\hline-12 & 0.772 & 16 & 0.232 & 44 & 0.29 & 72 & 0.296 & 100 & 0.323 \\
\hline-11 & 0.774 & 17 & 0.234 & 45 & 0.29 & 73 & 0.304 & & \\
\hline
\end{tabular}

The analysis of Table 3 first shows the significant fall of the index on the announcement date and the following day. Note that these first results are in line with the study of Warner (1977) reporting that the negative effect of the disclosure was quickly grasped by the stock market. Second, we observe, that the day on which the index shows its lowest value corresponds to the sixteenth day after the announcement. The negative trend in stock prices of our sample of firms under judicial protection procedure seems to be reversing from sixteen days after the announcement. So, we based on this "turning point" to build the following two indexes (step 2) before comparing them.

During the second step of our methodology, we first considered the two subsamples ("failing companies and their "lookalikes") separately. For each company, we compared up to 100 days after the event, the share price of each day with the basic share price (price on day 16). Thus, for the development of each index, we calculated, for each of the 139 days of the considered period, 152 index values, a mean is then calculated per day.

Figure 2 shows the values of our two indexes. 


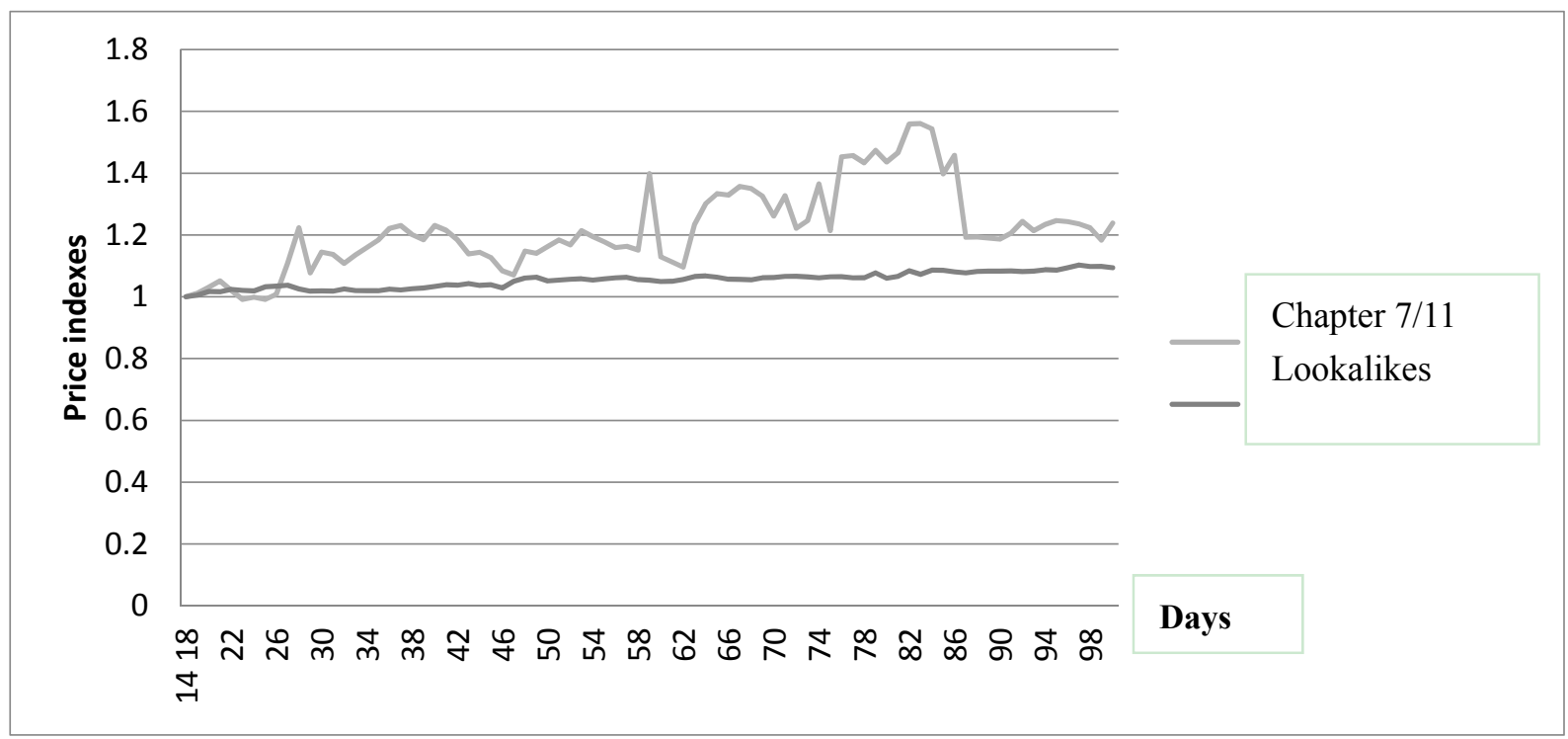

Figure 2. Evolution of indexes of share prices for both subsamples

The analysis of Figure 2 indicates that, over the period between 16 and 100 days after the possible implementation of a bankruptcy protection process, shares linked to companies involved in a process of liquidation or reorganization, show higher profitability. Possible developments regarding the situation of these companies, such as advances related to the plan of reorganization may, to some extent, explain this phenomenon. Furthermore, this comparative analysis allows to note that the differential of profitability is especially important around 80 days after the potential notification for a judicial protection procedure. Let us observe that an investment in a basket of shares of companies in difficulty, between 16 and 83 days after the announcement, allows benefiting from an appreciation of the corresponding index to $56 \%$ instead of only $7 \%$ for an investment in a basket of comparable companies not involved in liquidation or reorganization procedure. The explanation could be that being listed on the OTC market (even if less regulated) forces companies to take rapid organizational and financial strategic resolutions that generate value. These resolutions perhaps would not have taken if they had not been under judicial protection.

Finally, to rule more formally on the average superiority of the index mirroring the prices of securities backed to our bunch of firms placed under legal protection, we undertook a means comparison test between the mean values of our two indexes for the period between 16 and 100 days after the possible release of our reference event. Fisher's test (Table 4) leads us to reject the null hypothesis of equal variances at the threshold of $5 \%$ and, therefore, to consider the means comparison test proposed by Welch.

Table 4 . Test of equality of variances

\begin{tabular}{llll}
\hline Variable & $\begin{array}{l}\text { Variance } \\
\text { Chap. 7/11 }\end{array}$ & $\begin{array}{l}\text { Variance } \\
\text { «lookalikes » }\end{array}$ & F Stat \\
\hline $\begin{array}{l}\text { Index of price } \\
\text { value }\end{array}$ & 0.018 & 0.0006 & 29.72 \\
\hline
\end{tabular}

Table 5 shows the results of the means comparison test.

Table 5. Means comparison for the two indices

\begin{tabular}{llllll}
\hline Variable & \multicolumn{2}{c}{ Chap. 7/11 } & \multicolumn{2}{c}{ «Lookalikes » } & \multicolumn{2}{l}{$\begin{array}{l}\text { Comparison of average } \\
\text { values }\end{array}$} \\
\cline { 2 - 6 } & Mean & SD & Mean & SD & t-stat \\
index price & 1,218 & 0,134 & 1,053 & 0,024 & $10.923^{*}$ \\
\hline
\end{tabular}

*: Significant results at the $1 \%$ threshold. 
The analysis of Table 5 first shows that we can reject the null hypothesis of equality mean values of our two indexes. Second, the positive sign of the Student statistic shows the superiority of the average index linked to companies under judicial protection, which tends to support the results of studies of Altman (1998), Hotchkiss and Mooradian (1997), Indro et al. (1999) and Chi and Tang (2005). Third, the latter index shows a standard deviation significantly higher than the index mirroring the evolution of the price of securities "backed" to the "lookalikes". If it is possible to conclude to the average superiority of the index mirroring the prices of securities "backed" to our bunch of firms placed under legal protection in terms of profitability, let us note that these shares show a significant risk in comparison with that recorded for the "lookalikes".

\section{Discussion and Conclusion}

The aim of this article was to analyze the profitability of companies from U.S. equity markets around the announcement of filing for liquidation or reorganization procedure, and, so to figure out the behavior of the concerned investors whose profile was described by Kumar (2009). In order to pinpoint a potential attractiveness of these companies for investors, we have, through an original methodology, compared our bunch of failing firms to a sample of "lookalikes" having not experienced difficulties leading to resort to a bankruptcy protection procedure. Beyond the comparative perspective, this approach enables to circumvent some drawbacks inherent in the conventional event methodologies. In addition, this methodology may be of interest for other types of comparative analyzes for which conventional event methodologies are frequently used, such as the impact of releases of mergers and acquisitions.

Regarding the impact of the notification of a bankruptcy protection procedure for the few days around it, there is a drop in the index for these companies. This observation, in line with the findings of Warner (1977), implies that the disclosure of the event is regarded by the shareholders as the signal of potential problems that are inherent to the company (Clark and Weinstein, 1983) which could quickly lead to a complete termination of the business. The analysis of our results indicates, among other things, that these negative effects are felt up to twenty days after the notification. This is in line with the results of the study of Altman (1971) reporting a significant capital loss for shareholders over the period up to one trading month after the release of the announcement.

Our comparative analysis, based on a personal methodology involving the construction of price indexes, allows us to observe the existence of a significant difference in profitability between our two sub-samples. A strategy of investment in the basket of representative stocks of companies under judicial protection between days 16 and 83 after the announcement seems more profitable than an investment in comparable companies not affected by problems related to bankruptcy. This is in line with the findings of Hotchkiss and Mooradian (1997), Indro et al. (1999) and Chi and Tang (2005) reporting that the returns of securities under judicial protection can be positive and significantly higher than those of securities not involved in this procedure. These results could be due to some particular events inherent to the situation of companies under judicial protection such as the development of the plan or its acceptance by the Court (Morse and Shaw, 1988). In our bunch of failing companies, let us consider, for example, the case of American Home Mortgage stock whose price has increased by respectively 10, 9 and $17 \%$ three days after the disclosure of the acceptance by the Court to sale certain financial assets. Presumably the low share price has attracted new shareholders with a highly speculative profile. Let us also note that, if the profitability of securities backed to companies under a liquidation or reorganization procedure turns out to be higher, the risk is also higher. This result is in line with as Kumar (2009) reporting a speculative behavior of investors on these markets.

Note however that the results of our analyses are linked to our sample as well as the chosen period, it would be relevant to lead a similar study on a different time horizon in order to compare and strengthen our results.

\section{References}

Aglietta, M. (2008). Les crises financières : plus ça change, plus c'est la même chose. Revue d'Economie Financière, 7, 39-45. http://dx.doi.org/10.3406/ecofi.2008.5183

Aharony, J., Jones, C. P., \& Swary, I. (1980). An analysis of risk and return characteristics of corporate bankruptcy using capital market data. The Journal of Finance, 35(4), 1001-1016. http://dx.doi.org/10.1111/j.1540-6261.1980.tb03516.x

Altman, E. (1971). Corporate bankruptcy in America. Heath Lexington Books.

Altman, E. (1998). Market dynamics and investment performance of distressed and defaulted debt securities. New York University Working paper, p23. 
Altman, E., \& Brenner, M. (1981). Information effects and stock market response to signs of firm deterioration. The Journal of Financial and Quantitative Analysis, 16(1), 35-51.

Attali, J. (2008). La crise, et après? Paris, Fayard.

Beaver, W. (1968). Market prices, financial ratios, and the prediction of failure. Journal of Accounting Research, 6(2), 179-192. http://dx.doi.org/10.2307/2490233

Brédart, X., \& Finet, A. (2012). La rentabilité des entreprises sous protection judiciaire. La Revue des Sciences de Gestion. 2(254), 13-22.

Bris, A., Welch, I., \& Zhu, N. (2006). The costs of bankruptcy: chapter 7 liquidation versus chapter 11 reorganization. The Journal of Finance, 61(3), 1253-1303. http://dx.doi.org/10.1111/j.1540-6261.2006.00872.x

Chen, K., \& Church, B. (1996). Going concern opinions and the market's reaction to bankruptcy filings. The Accounting Review, 71(1), 117-128.

Chi, L.C., \& Tang, T.C. (2005). Artificial neural networks in reorganization outcome and investment of distressed firms: the Taiwanese case. Expert Systems with Applications, 29(3), 641-652. http://dx.doi.org/10.1016/j.eswa.2005.04.021

Chi, L.C., \& Tang, T.C. (2007). Impact of reorganization announcements on distressed-stock returns. Economic Modelling, 24(5), 749-767. http://dx.doi.org/10.1016/j.econmod.2007.02.007

Clark, T., \& Weinstein, M. (1983). The behaviour of the common stock of bankrupt firms. The Journal of Finance, 38(2), 489-504. http://dx.doi.org/10.1111/j.1540-6261.1983.tb02257.x

Eberhart, A., Aggarwal, R., \& Altman, E. (1999). The equity performance of firms emerging from bankruptcy. The Journal of Finance, 54(5), 1855-1868. http://dx.doi.org/10.1111/0022-1082.00169

Gilson, S. (1989). Management turnover and financial distress. Journal of Financial Economics, 25(2), 241-262. http://dx.doi.org/10.1016/0304-405X(89)90083-4

Hotchkiss, E., \& Mooradian, R. (1997). Vulture investors and the market for control of distressed firms. Journal of Financial Economics, 43(3), 401-432. http://dx.doi.org/10.1016/S0304-405X(96)00900-2

Indro, D., Leach, R., \& Lee, W. (1999). Sources of gains to shareholders from bankruptcy resolution. Journal of Banking and Finance, 23(1), 21-47. http://dx.doi.org/10.1016/S0378-4266(98)00075-2

Jessup, \& Upson, R. (1970). Opportunities in regional markets. Financial Analysts Journal, 26(2), 75-79. http://dx.doi.org/10.2469/faj.v26.n2.75

Kalay, A., Singhal, R., \& Tashjian, E. (2007). Is chapter 11 costly?. Journal of Financial Economics, 84(3), 772-796. http://dx.doi.org/10.1016/j.jfineco.2006.04.001

Kumar, A. (2009). Who gambles in the stock market?. The Journal of Finance, 64(4), 1889-1933.

Li, Y., \& Zhong, Z. (2013). Investing in chapter 11 stocks: trading, value and performance. Journal of financial markets, 16, 33-60. http://dx.doi.org/10.1016/j.finmar.2012.09.006

Morse, D., \& Shaw, W. (1988). Investing in bankrupt firms. The Journal of Finance, 43(5), 1193-1206.

Mossman, C.E., Bell, G.G., Swartz, L.M., \& Turtle, H. (1998). An empirical comparison of bankruptcy models. Financial Review, 33(2), 35-54. http://dx.doi.org/10.1111/j.1540-6288.1998.tb01367.x

Thomas, L., \& Cunney, J. (2004). The chapter after chapter 11. New York. J.P.Morgan studies.

Warner, J. (1977). Bankruptcy, absolute priority, and the pricing of risky debt claims. Journal of Financial Economics, 4(3), 239-276. http://dx.doi.org/10.1016/0304-405X(77)90002-2

Welch, B.L. (1938). The significance of the difference between two means when the population variances are unequal. Biometrika, 29(3-4), 350-362. http://dx.doi.org/10.1093/biomet/29.3-4.350

\section{Notes}

Note 1. For each "lookalike", setting the day number '0'corresponds to the announcement date of judicial protection of its "twin".

Note 2. Note that the exclusion of an observation of the sample of firms under judicial protection entails the de facto abolition of the "lookalike".

Note 3. SIC stands for Standard Industrial Classification. 